\title{
CORAL REEFS ON INHABITED AND UNINHABITED SMALL ISLANDS, SPERMONDE ARCHIPELAGO, INDONESIA
}

\author{
Nurjannah Nurdin ${ }^{1,4^{*}}$, Khairul Amri ${ }^{1}$, Abd Rachman Rasyid ${ }^{2}$, Dwia Aries Tina Pulubuhu ${ }^{3}$, Nurliah Nurdin ${ }^{5}$, Teruhisa Komatsu ${ }^{6,7}$ \\ ${ }^{1}$ Marine Science and Fisheries Faculty, Hasanuddin University, Makassar, 90245, Indonesia; nurj_din@yahoo.com \\ ${ }^{2}$ Engineering Faculty, Hasanuddin University, Gowa, 92172, Indonesia \\ ${ }^{3}$ Sociology Department, Hasanuddin University, Makassar, 90245, Indonesia \\ ${ }^{4}$ Research and Development Center for Marine, Coast, and Small Island, Hasanuddin University, Makassar, 90245, Indonesia; \\ ${ }^{5}$ Institute of Domestic Governance, Jatinangor, 45363. Indonesia \\ ${ }^{6}$ Atmosphere and Ocean Research Institute, The University of Tokyo, Kashiwa 277-8564, Japan \\ ${ }^{7}$ Present affiliation: Yokohama College of Commerce, Yokohama 230-8577, Japan
}

KEY WORDS: coral reef ecosystem, human impact, spatio-temporal change, remote sensing, Landsat

\begin{abstract}
The small islands in Indonesia is providing important ecosystem services. It is important to identify damages of a coral reef ecosystem and whether natural factors or anthropogenic factors are the main causes. Landsat images obtained with different sensors were analyzed for mapping coral reef on inhabited and uninhabited small islands, Spermonde archipelago, Indonesia. Overall accuracies of three habitats classification were $89.2 \%$ and $85.6 \%$, respectively. They are live coral, dead coral and non-coral. Ground truth surveys were selected by using the unsupervised classification method The live coral in inhabited islands was slightly greater than in uninhabited. An increasing area of live coral was about 5.3 ha of the total area in 1990 per year while a decreasing of dead coral was 3.5 ha per year in inhabited islands. In uninhabited island, a decreasing speed of live coral habitat area was about 0.6 per year. During 29 years, a significant increase in the dead coral and decrease in live corals. It has been identified that the significant controlling factor for the disturbances in reef ecosystem is derived from natural and anthropogenic.
\end{abstract}

\section{INTRODUCTION}

Coral reef ecosystems are under enormous pressure from human use and global climate change (Halpern et al., 2008). Direct human impacts range from overfishing and physical damage such as through dynamite fishing and reef clearance, to eutrophication and other forms of pollution via coastal runoff and nearshore discharge, as well as in the application of chemical toxins such as in cyanide fishing (Hughes et al., 2014). Indirect human impacts include rising air and sea surface temperatures associated with coral bleaching plus ocean acidification driven by anthropogenic greenhouse gas emissions (Feely et al., 2004; Hoegh-Guldberg et al., 2007). With increasing human reach around the globe, even the most remote oceanic islands is threatened.

The efforts to accurately monitor and assess the changes in coral reef community composition by satellite imagery is now increasing in the scientific community at a variety of spatial and temporal scales. (Jupp et al., 1985 and Levine, AS et al., 2015) have shown that the use of satellite imagery for mapping coral reefs constitutes a valuable approach. On the contrary for the small islands, the use of an satellite may be the most appropriate for mapping and monitoring the coral reefs. The OLI_TIRS sensor on board the Landsat- 8 spacecraft provides the capability to assessment of coral reefs at a global scale (Spaldinga, M et al., 2017). The main objective of this study is to evaluate the capabilities of different remote sensors to provide data that is useful for assessing coral reef status and dynamic changes of live to dead coral on two different islands. They are inhabited and uninhabited islands.

\section{MATERIAL AND METHODS}

\subsection{Field study}

The islands for research are located in the waters of the Spermonde Archipelago and belong to the Liukang Tupabiring District in South Sulawesi Province, Indonesia, as shown in Figure 1. They were divided into two island categories: small inhabited islands, and small uninhabited islands. Three small inhabited islands were selected as representative locations: a) Ballang Lompo (BL), b) Karanrang (KR), c) Bonetambung (BT), and those in the uninhabited island category were Kodingareng Keke (KK) and Samatellu Pedda (SP) Islands. The 3 inhabited islands and 2 uninhabited islands were selected based on availability of ground truthing data obtained in 2016 and 2018/2019 because of financial limitation of the study.

\subsection{Data}

This Study used Landsat with sensor TM, ETM and OLI to analysis coastal ecosystem. The Landsat imagery data recorded in 1990, 1996, 2002, 2008, 2016, 2018 and 2019 through EarthExplorer (http://earthexplorer.usgs.gov/).

*Corresponding author: Nurjannah Nurdin (nurj_din@ yahoo.com) 


\begin{tabular}{ccccl}
\hline No & Satelite & Sensor & Resolution $(\mathbf{m})$ & \multicolumn{1}{c}{ Acquisition } \\
\hline 1 & Landsat 4 & TM & 30 & 16 December 1990 \\
\hline 2 & Landsat 5 & TM & 30 & 28 April 1996 \\
\hline 3 & Landsat 7 & TM & 30 & 24 June 2002 \\
\hline 4 & Landsat 7 & ETM & 30 & 19 August 2008 \\
\hline 5 & Landsat 8 & OLI_TIRS & 30 & 10 September 2016 \\
\hline 6 & Landsat 8 & OLI_TIRS & 30 & 25 April 2018 \\
\hline 7 & Landsat 8 & OLI_TIRS & 30 & 06 January 2019 \\
\hline
\end{tabular}

Table 1. Data of LANDSAT images analyzed in this study

\subsection{Image processing}

Satellite image data processing was conducted to determine the distribution and condition of coral reefs with ArcGIS (ESRI Co), consisting of geometric and radiometric corrections of satellite images, atmospheric correction with a dark object subtraction (DOS) module, image pan-sharpening, water column correction with a depth invariant index method, conducting unsupervised classification, determining ground truth, making an accuracy assessment and conducting reclassification.
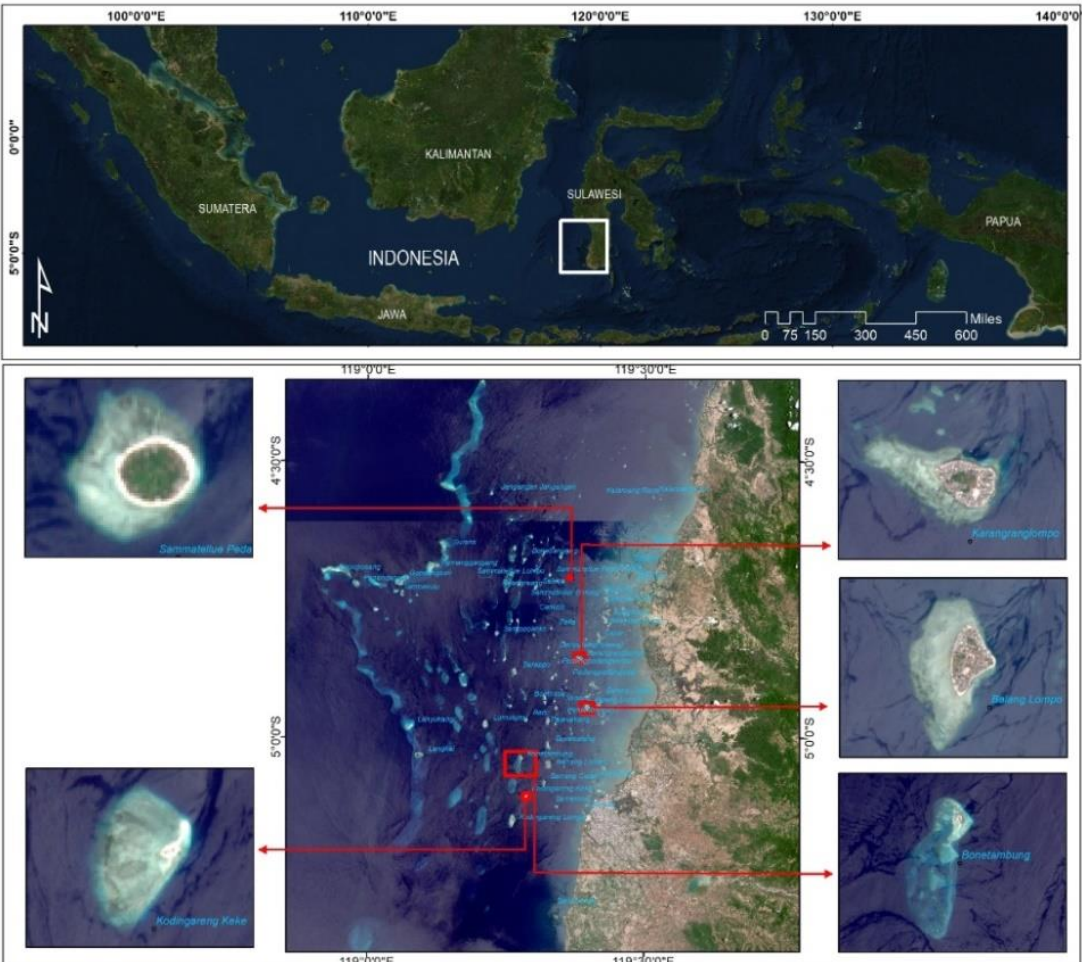

Figure 1. Ground truthing location on Spermonde archipelago

Geometric errors in the original images were corrected by rectification based on existing Ground Control Points (GCPs) through placing a pixel image in an actual position on the surface of the earth. Atmospheric correction was conducted using radiometric calibration (DN to reflectance) and Dark Object Subtraction (DOS) to remove the atmospheric effect on the image assuming the darkest pixel value was zero (Chavez, 1988).

Water column correction (Depth Invariant Index) Corrected images were used to classify shallow-water habitats and coral reef condition using supervised classification.

The Depth water column correction method applied was the Invariant Index (DII) by Lyzenga, 1981. The DII method reduces the influence of the water column so that a clearer image of the shallow water habitat could be obtained. Points on the sand area were used to build a model to obtain the attenuation coefficient of the water column. This is because sand objects are easier to recognize, which appears bright white and darker blue as the water depth increases. The algorithm used in this process was:

$$
\mathrm{DII}=(\log (\mathrm{Xi})+[(\mathrm{Ki} / \mathrm{Kj}) * \log (\mathrm{Xj})]) / \sqrt{ } 1+\left[\frac{K i}{K j}\right]^{2} \ldots
$$

DII $=$ Depth Invariant Index $; \mathrm{Li}=\mathrm{i}$-band reflectance value $; \mathrm{Lj}$ $=\mathrm{j}$-band reflectance value; $\mathrm{ki} / \mathrm{kj}=\mathrm{i}$ and $\mathrm{j}$ band attenuation coefficient ratio; $\alpha \mathrm{i}=\mathrm{i}$-band variant; $\alpha \mathrm{j}=\mathrm{j}$-band varian; $\alpha \mathrm{ij}=\mathrm{i}$ and $\mathrm{j}$ band covariant

The sharpening from Landsat image process was done to facilitate interpretation for image classification. Observation points for ground truth surveys were selected by using the unsupervised classification method, ISODATA (iterative selforganizing data analysis technique) algorithm to group 
multispectral image pixels into relatively homogeneous groups based on maximum standard deviations.

Ground truth data at the observation points are related to unsupervised classes. The classes having the same object based on the ground truth data are also merged into one class.

The accuracy test used a confusion matrix comparing habitat classes resulting from image classification against actual classes from those of the ground truth survey. The expected accuracy value must meet the requirements and have a significance of more than $60 \%$, so that the results of the overall accuracy in percentage and the kappa accuracy can be used as proof of image classification accuracy. Kappa accuracy is expressed as follows:

$$
K a p p a=\frac{N \sum_{i=1}^{r} X_{I I}-\sum_{i=1}^{r}\left(X_{i+} * X_{+i}\right)}{N^{2}-\sum_{i=1}^{r}\left(X_{i+} * X_{+i}\right)} \ldots \ldots .(2)
$$

Where $\mathrm{N}$ is the total number of cells in the matrix; $\mathrm{r}$ is the number of rows in the matrix; XII is the number in row $\mathrm{i}$ and column $\mathrm{i} ; \mathrm{x}+\mathrm{i}$ is the total observations for column $\mathrm{I}$ and $\mathrm{xi}+$ is the total number of observations in row $\mathrm{i}$.

\section{RESULTS AND DISCUSSION}

\subsection{Overall accuracy of ISODATA classification of Landsat images in 2019}

The accuracy of the habitat map was assessed using a standard error matrix. Data from 297 sites on inhabited island and 97 sites on uninhabited island were ground truthed visually by boat and geo-coordinate data were collected at each site. The actual sites were then compared to the predicted cover types in the classified map to produce the overall accuracy of the map (Campbell, 1996). Producer's accuracy is the probability that the predicted class actually represents what is on the ground and is useful for assessing the accuracy of the individual informational classes (Mumby et al., 1997). The accuracy assessment showed overall accuracies of $89.23 \%$ for the three habitats types (i.e., live coral, dead coral, and non- coral for Inhabited and $85.57 \%$ for Uninhabited island. Therefore, we applied the method to images for other years supposing that the unsupervised classification can classify the LANDSAT images for other years at an accuracy of classification sufficient for mapping similar to that for 2019.

\subsection{Time series imagery of coral reefs in Inhabited islands}

Determination of various coral reefs classes, i.e., live coral and dead coral may be determined by developing a classification scheme to get a broad level of classification . Live coral in three inhabited island have decreased areas 16.09 ha on KR island, 98.94 ha on BT island and 38.56 ha on BL Island from 1990 to 2019. Live coral and dead coral mostly on west part of the islands. Deforestation highly occurred on inhabited island in 1996-2002.

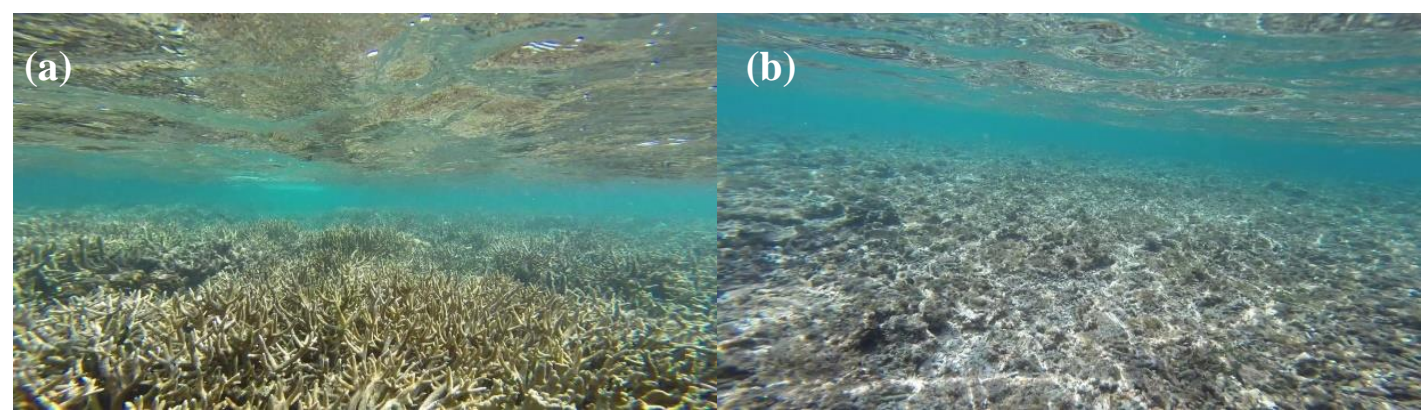

Figure 2. Coral Reef Condition in BL Island: (a) Good Condition; (b) Dead Coral due destructive fishing

Live corals on the three populated islands have seen a decline from 1990 to 2019 using spatial analysis. live corals have decreased by 16.09 ha $(76 \%)$ on KR island, 98.94 ha $(85 \%)$ on BT island, and 38.56 ha (84\%) on BL island until 2019. 23\%) on KR island, 19.79 ha (30\%) on BT island, and 7.71 ha (30\%) on BL island. Dead coral on three populated islands has seen an increase in area from 1990 to 2019. The area of dead coral has increased by 5.00 ha (40\%) on KR island, 68.78 ha $(52 \%)$ on BT island, and 26.91 ha $(65 \%)$ in BL island until 2019. The average area of dead corals that increased annually was 1.00 ha (9\%) on KR island, 13.76 ha (13\%) on BT island, and 5.38 ha $(19 \%)$ on BL island (Table 2$)$.

Changes in coral reef habitat on three inhabited islands indicate that the area of live coral habitat has decreased significantly in the period 1996-2002. Changes in living coral habitat are thought to be influenced by global climate change, namely the 1997 El Nino and 1999 El Nina phenomena (Fitria and
Pratama, 2013). The influence of global climate causes changes in sea surface temperature, resulting in coral bleaching of living corals (Wouthuyzen et al., 2020). Meanwhile, the period 20022019, which shows a decrease in live coral habitat, can be caused by the increasing intensity of human activities (Turak and DeVantier, 2008). One of the human activities that greatly impacts the survival of coral reefs is dumping garbage into the sea. Marine debris that covers coral reefs can cause zooxanthella to be unable to carry out photosynthesis and ultimately lead to coral death (Ilham et al., 2017). 


\begin{tabular}{|c|c|c|c|c|c|c|}
\hline Live Coral & & & Area (F & & & \\
\hline Islands & 1990 & 1996 & 2002 & 2008 & 2016 & 2019 \\
\hline Bonetambung & 115.99 & 100.88 & 52.93 & 30.19 & 22.39 & 17.06 \\
\hline Ballang Lompo & 46.17 & 37.62 & 21.76 & 17.68 & 12.73 & 7.61 \\
\hline Karanrang & 21.24 & 20.34 & 15.48 & 10.73 & 6.01 & 5.15 \\
\hline Dead Coral & & & Area (F & & & \\
\hline Bonetambung & 62.31 & 73.91 & 100.51 & 121.57 & 129.31 & 131.08 \\
\hline Ballang Lompo & 14.22 & 18.27 & 26.72 & 34.88 & 34.40 & 41.13 \\
\hline Karanrang & 7.65 & 7.65 & 9.14 & 10.31 & 11.86 & 12.65 \\
\hline
\end{tabular}

.Table 2. Areas of live coral and dead coral habitats in Inhabited Islands

The habitat of coral reefs on populated islands is Morotai Island, North Maluku Province (Wahiddin et al., 2014). The condition of coral reefs in 1996-2013 underwent significant changes. The changes show that in the period 1996-2002 there was a decrease in the area of live coral by 103.05 ha $(16.6 \%)$ and in the 2002-2013 period there was a decrease in the area of live coral by 140.31 ha $(27 \%)$. In a period of 17 years, coral reef mortality was around $43.6 \%$. This may be due to an increase in sea water temperature and an increase in the intensity of human activities. The change of life coral and dead coral in inhabited island can be seen in Figure $3 \& 4$.
(A)

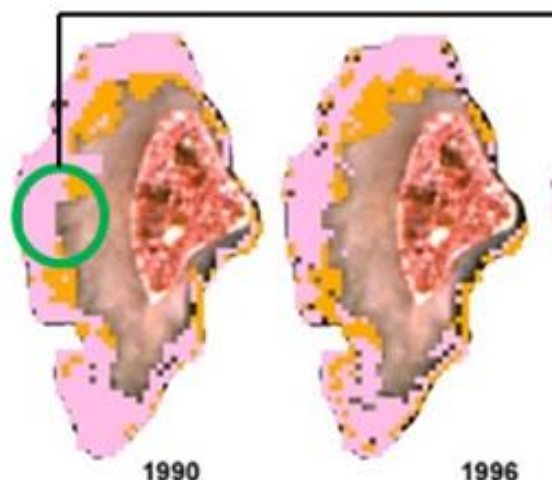

1996

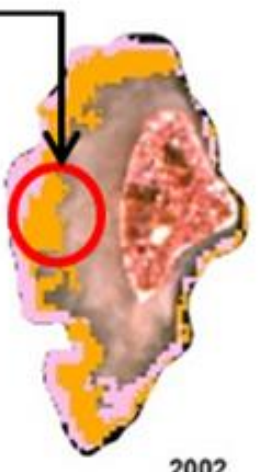

2002

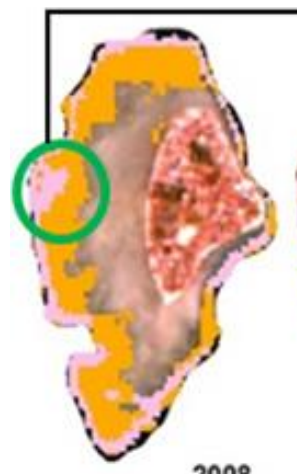

2008

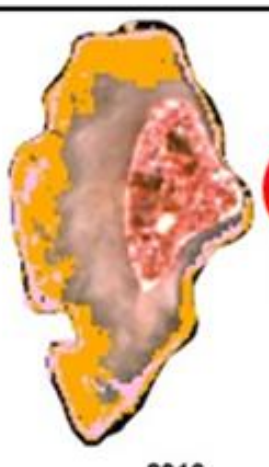

2n16

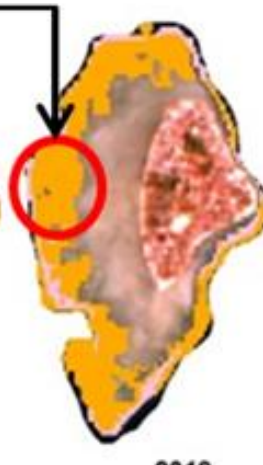

2019
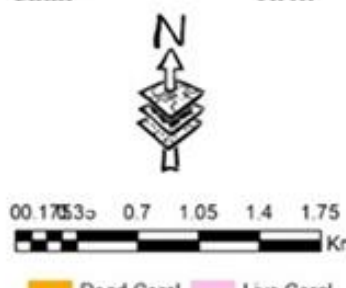

Dead Coral Live Coral
(B)
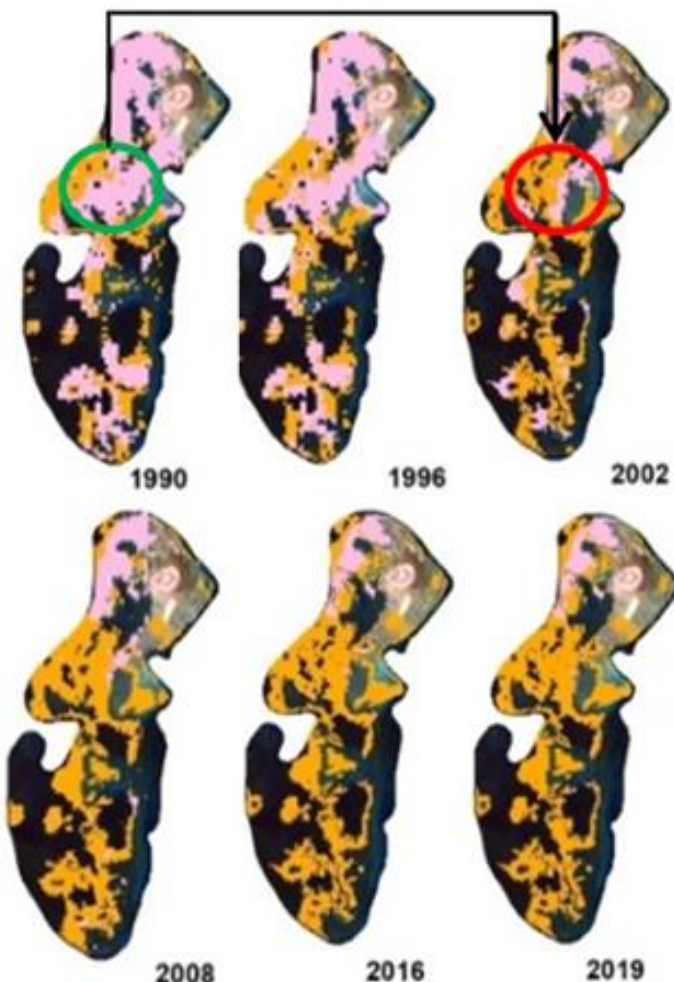

2016

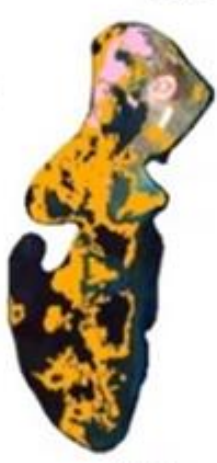

2019
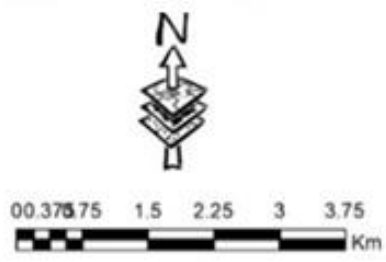

Dead Coral Live Coral

Figure 3. The arrow direction shows the widest change from live coral to dead coral at the same location but at different times in $\mathrm{BL}$ island (A) and BT island (B) with residents from 1990 to 2019. 


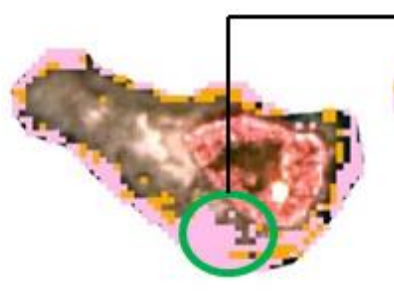

1990

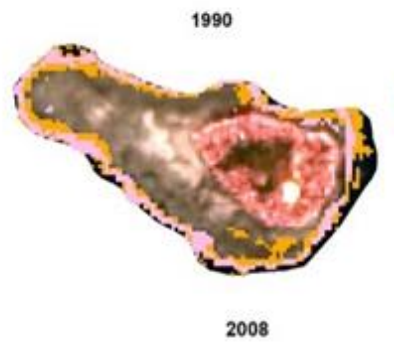

2008

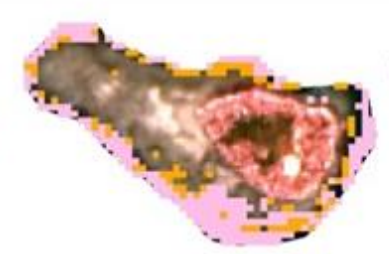

1996

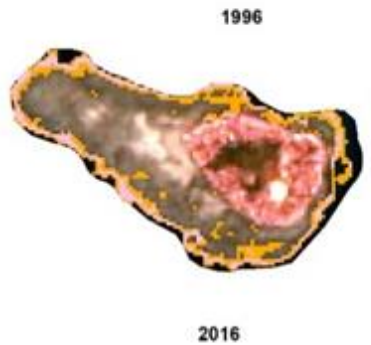

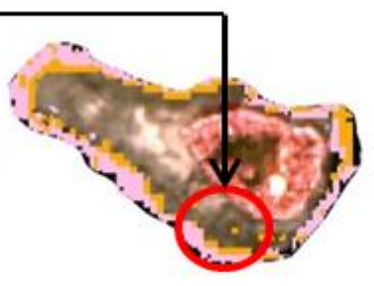

2002

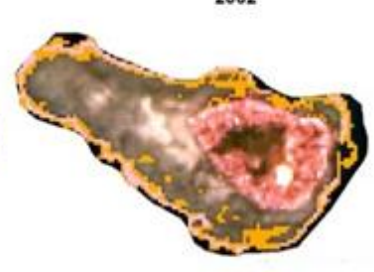

2019

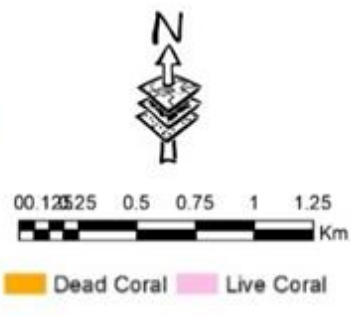

Figure 4. The arrow direction shows the widest change from live coral to dead coral at the same location but at different times in KR island with residents from 1990 to 2019.

\subsection{Time series imagery of coral reefs in Uninhabited Islands}

Live coral on two non-populated islands has decreased from 1990 to 2019. The area of live coral has decreased by 14.17 ha (69\%) in KK, and 4.43 ha (76\%) on SP island until 2019. live coral decreased annually by 2.83 ha $(19 \%)$ in KK, and 0.89 ha (24\%) in SP island. However, Dead coral on three populated islands has seen an increase in area from 1990 to 2019. The area of dead corals has increased by 8.17 ha $(65 \%)$ on KK island and 3.09 ha $(67 \%)$ on SP island in 2019. The average dead corals increased annually by an area of 1.63 ha (18\%) in $\mathrm{KK}$, and $0.62 \mathrm{ha} \mathrm{(19 \% )} \mathrm{in} \mathrm{SP} \mathrm{island} \mathrm{(Table} \mathrm{3).}$

Changes in coral reef habitat on uninhabited islands indicate that the area of live coral habitat has decreased and the area of dead coral habitat has increased. On KK island, there was a significant decrease in live corals in the 2002-2008 period of 8.87 ha, but the dead corals did not change in the 1996-2002 period. Meanwhile, on SP island, the highest change in live coral area occurred in the 1996-2002 period of 1.72 ha.

\begin{tabular}{lccccccr}
\hline Live Coral & \multicolumn{7}{c}{ Area (Ha) } \\
\hline Islands & $\mathbf{1 9 9 0}$ & $\mathbf{1 9 9 6}$ & $\mathbf{2 0 0 2}$ & $\mathbf{2 0 0 8}$ & $\mathbf{2 0 1 6}$ & $\mathbf{2 0 1 6}$ GT 2019 & $\mathbf{2 0 1 8 / 2 0 1 9}$ \\
\hline Kodingareng Keke & 20.43 & 16.83 & 17.54 & 8.67 & 6.57 & 8.89 & 6.26 \\
\hline Samatellu Peda & 5.82 & 4.59 & 2.87 & 1.78 & 1.69 & 1.39 & 1.40 \\
\hline Dead Coral & & & \multicolumn{7}{c}{ Area (Ha) } \\
\hline Islands & $\mathbf{1 9 9 0}$ & $\mathbf{1 9 9 6}$ & $\mathbf{2 0 0 2}$ & $\mathbf{2 0 0 8}$ & $\mathbf{2 0 1 6}$ & $\mathbf{2 0 1 6}$ GT 2019 & $\mathbf{2 0 1 8 / 2 0 1 9}$ \\
\hline Kodingareng Keke & 4.32 & 6.30 & 6.30 & 10.29 & 12.11 & 10.64 & 12.49 \\
\hline Samatellu Peda & 1.52 & 2.34 & 2.95 & 3.49 & 4.21 & 3.94 & 4.61 \\
\hline
\end{tabular}

Table 3. Areas of live coral and dead coral habitats in uninhabited Islands

Changes in the area of coral reefs on uninhabited islands can be caused by fishing activities on the island. The coral reefs on uninhabited islands are more likely to be affected by the bombing of fish, because there are no people who inhabit and protect the islands. As for the impact of the damage caused by the bomb, namely deadly, dismantling and breaking coral in a fairly wide scope and depending on the strength of the bomb, so that the bigger the bomb is thrown away, the greater the impact of the damage it will produce. In addition, mining of sand and coral as building materials to be brought to the inhabited islands has also occurred on the island of Bone Batang. This is also one of the factors causing the destruction of coral reefs, due to uncontrolled taking of corals. In addition, sand that is stirred up during mining is carried away and allows covering of coral polyps (Ilham et al., 2017). 


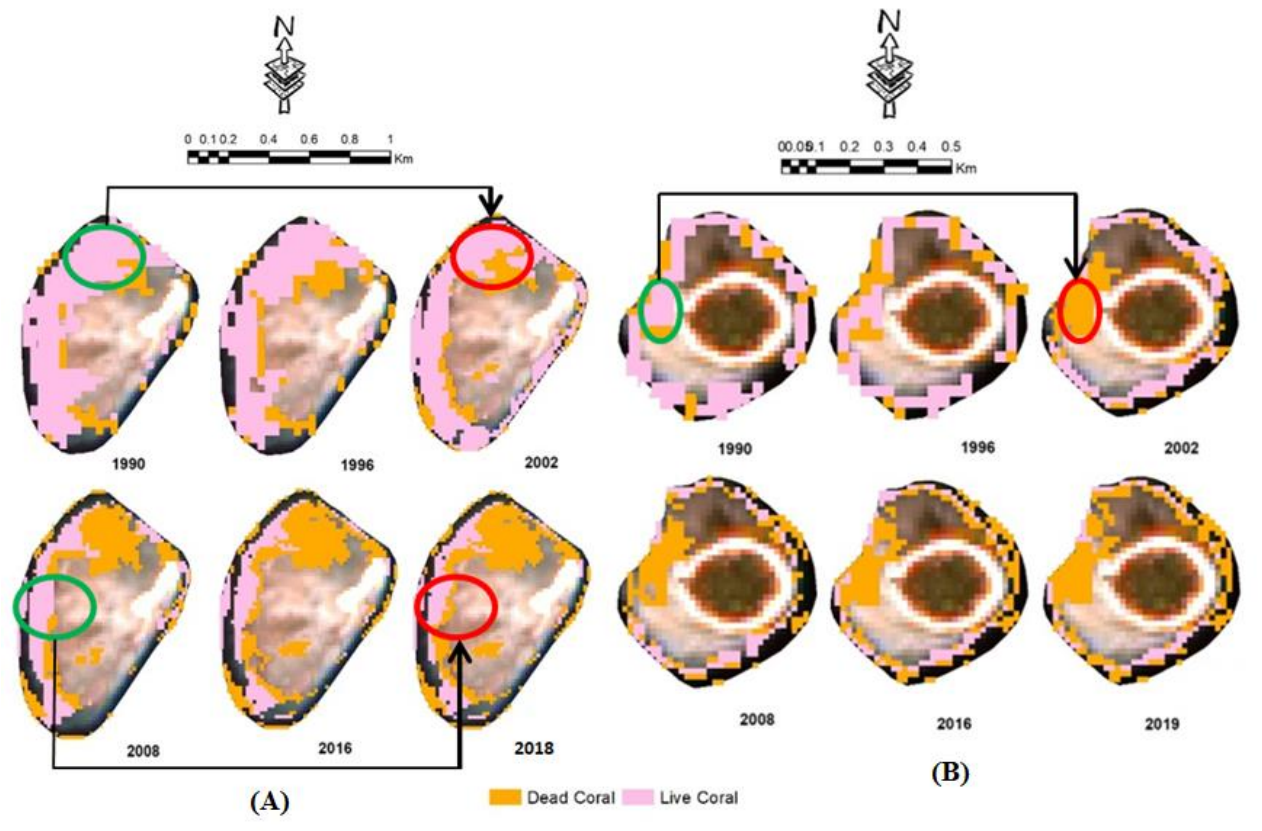

Figure 5. The arrow direction shows the widest change from live coral to dead coral at the same location but at different times in KK island (A) with non-residents from 1990 to 2018 and in SP island (B) with residents from 1990 to 2019.

\subsection{Dynamic of coral reef habitats in Inhabited and Uninhabited islands}

We compared two habitat areas inhabited and uninhabited islands. Figure 6 shows that the areas of live coral to the total area in each year from 1990 to 2019 when those in 1990 were set to 183.4 ha in inhabited islands. In both islands, the decreasing tendency was very clear. The decreasing speed of live coral habitat in inhabited islands was slightly greater than that in uninhabited. Areal of a live coral habitat was compared with dead coral habitat area in inhabited island. An increasing speed of live coral habitat area was about 5.3 ha of the total area of two habitats in 1990 per year while a decreasing speed of dead coral was 3.5 ha per year in inhabited islands (Fig. 6). In uninhabited island, a decreasing speed of live coral habitat area was about 0.6 ha of the total area per year while an increasing speed of dead coral habitat was 0.4 ha per year (Fig. $6)$.

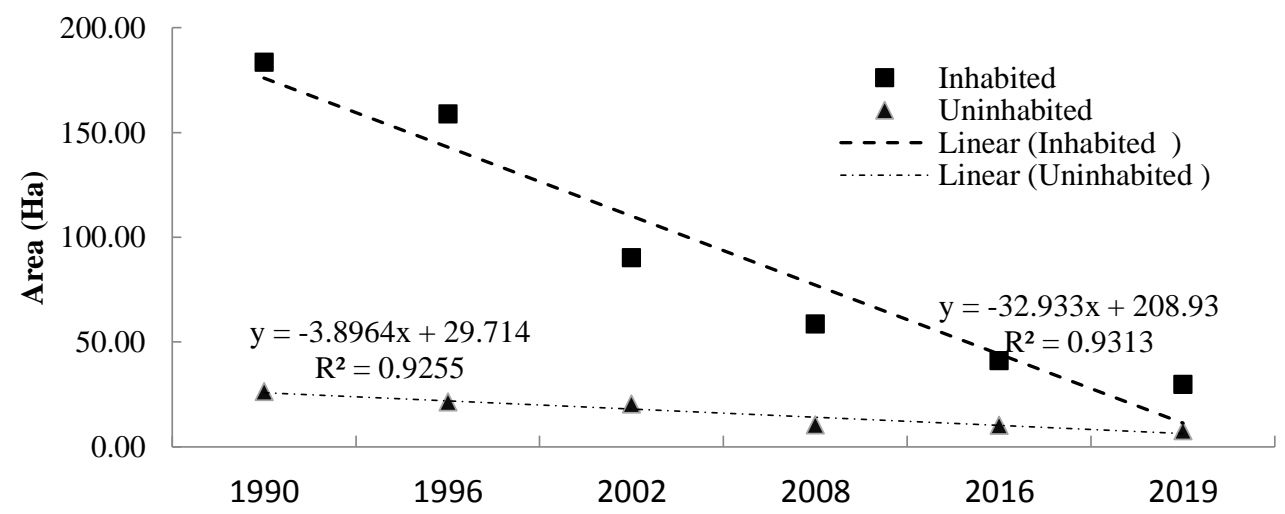

Figure 6. Area of live coral habitat in Inhabited and Uninhabited Islands obtained from analysis of the LANDSAT images

Human interaction with the natural environment has firmly increased, leading to negative impacts on the health and status of coral reefs in Spermonde archipelago since the 1960s (Nurdin, $\mathrm{N}$ et al., 2015, 2016). The significant addition of anthropogenic factors to live corals change was appraised using two complementary approaches, i.e. multi temporal image analysis, ground truthing and field interview surveys. Currently, human disturbances are more exhaustively documented, as they were firstly interpreted from satellite images, and secondly interview in the field. Although reef communities have evolved and persisted in the face of natural destructive processes, modern anthropogenic forces threaten to devastate reefs throughout the world, both directly and indirectly (Kleypas et al., 1999; Smith \& Buddemeier, 1992). Worst-case estimates of reef degradation predict that in the next 30 years, nearly half of the world's reefs may be permanently disappeared (Wilkinson, 2000). 
Accurate habitat maps of coral reef ecosystems, especially for reefs located in remote areas, are required. Affiliation of image with survey data in this study is fundamental for the mapping and validation process and to have non-remote sensing users to easily understand and get confidence in remote sensing and its effectiveness in mapping and monitoring coral reefs. Coral reefs on inhabited and uninhabited islands have been subjected to significant decline. They are damaged, displaced, polluted, stepped on, and blasted off, in addition to the effects of climate change on the reefs. One of the most vital issue affecting reef health is the mass coral bleaching that stimulated by an interaction between human activities and climatic changes.
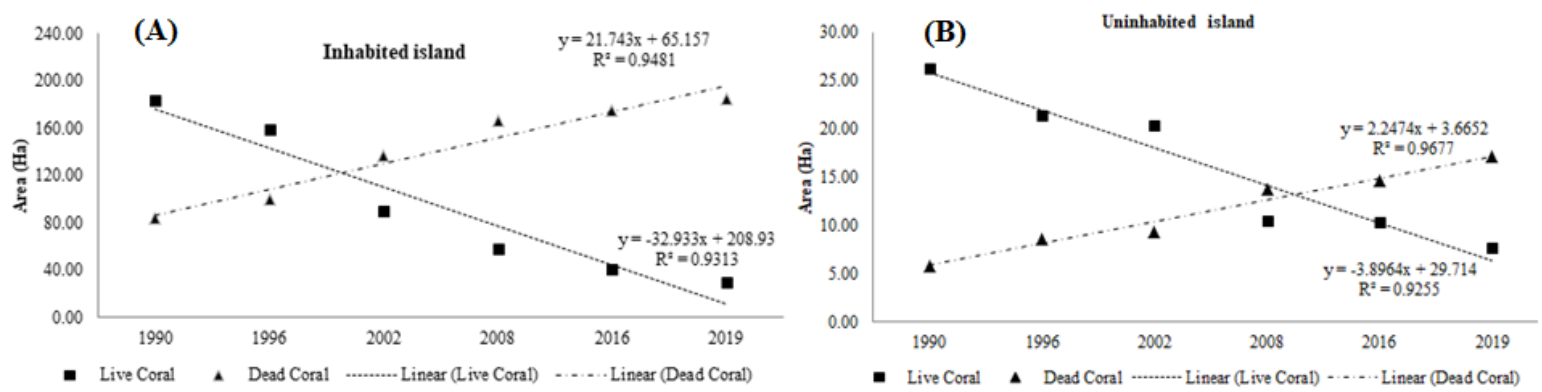

Figure 7. (A) Area of a live coral and dead coral habitats to the total area in Inhabited island (A) and in Uninhabited island (B) obtained from analysis of the LANDSAT images.

Techniques to detect changes highlight the variations from 1990 to 2019 landscapes in qualitative and quantitative approaches by subtracting the original and classified images. Thematic difference maps were combined with the statistical change detection. We looked at the dynamic shift of coral reefs over the four decades, due to spatial analysis and social impacts. During 29 years, a significant increase in the dead coral and decrease in live corals. It has been identified that the significant controlling factor for the disturbances in reef ecosystem is derived from natural and anthropogenic.

\subsection{Coral reefs management and anthropogenic}

This study shows that one of the main causes of the continued decline of coral reefs over a period of 29 years is illegal fishing. Prioritizing social norms that become natural regulations regarding the principle of using marine resources as a common property. The prohibition of fishing with explosives must be accompanied by several livelihood development options such as aquaculture and the intrusion of environmentally friendly fishing technologies.

The dead of coral reefs habitat is not only due to overfishing but also the pollutant materials (Nurdin \& Grydehoj, 2014 ) that last in the ocean. Coral Reef must be saved to the abundance living depend on it. Beside as income resources known as fishing industry, million people count on their protein (fishing local) and could be tourism sites. Therefore, Indonesia government has applied the harms against coral reef in the Law No 27 year 2007 on Small Islands Management . The law has sanction for any damaged of the coral reef caused by human actives; taken them in conservation, using bombing and destructive and poisons materials or any other ways that could banish the living of coral reef.

However, having the law for already 14 years, still the damaged occurred both in habited or inhabited islands. People live near by the islands who act against the coral reef life continuously impact neighborhood island. It is not only due to the weakness of law enforcement to implement the law but any government effort to pursued will not effective without an intensive training skill for alternative living income' source. People who live near in ocean count their live on the ocean live but they do not have a strong knowledge to preserve their income source which is the coral reef. Two efforts must be done immediately and simultaneously that are active education on the society as well as alternative living source by skill training.

\section{CONCLUSIONS}

There was a decrease in live coral and conversely there was an increase in dead coral on in inhabited and in uninhabited. The decreasing of live coral in inhabited islands was slightly greater than in uninhabited. Government can no longer count only the law to preserve the coral reef but having an actual program for the Islands society which education to live hand by hand with its natural income resource (coral reefs) and skill training for alternative income living.

\section{ACKNOWLEDGMENTS}

The Ministry of Research Technology and Higher Education of the Republic of Indonesia and the Research Center Institution of Hasanuddin University are support in providing research funds. Thank you to the Ocean Remote Sensing Project of Subcommission of Western Pacific Intergovernental Oceanographic Commission/UNESCO supported by Japan Fund in Trust provided by Ministry of Education, Culture, Sports, Science and Technology, Japan.

\section{REFERENCES}

Campbell, J.B., 1996. Introduction to Remote Sensing. New York: The Guilford Press.

Chavez Jr, P.S., 1988. An improved dark-object subtraction technique for atmospheric scattering correction for multispectral data. Remote Sensing of Environment 24, 459479 .

Feely, R.A.., C.L. Sabine, K., Lee, W., Berelson, J., Kleypas, V. J., Fabry., 2004. Impact of anthropogenic $\mathrm{CO}_{2}$ on the $\mathrm{CaCO}_{3}$ system in the oceans. Science $305,362-366$. 
Fitria, W., Pratama, M.S., 2013. Pengaruh Fenomena El Nino 1997 Dan La Nina 1999 Terhadap Curah Hujan Di Biak. Jurnal Meteorologi Dan Geofisika Vol. 14 No. 2 Tahun 2013 : 65-74.

Halpern, B.S., S. Walbridge., K. A., Selkoe C.V., Kappel F., Micheli C., Agrosa., 2008. A global map of human impact on marine ecosystems. Science 319, 948.

Hoegh-Guldberg, O., P.J. Mumby, A.J., Hooten, R.S., Steneck, P., Greenfield, E., Gomez, C.D., Harvell, P.F., Sale, A.J., Edwards, K., Caldeira., 2007. Coral reefs under rapid climate change and ocean acidification. Science, 318:1737-1742.

Hughes, T.P., D.R. Bellwood, S.R., Connolly, H.V., Cornell., R. H. Karlson., 2014. Double jeopardy and global extinction risk in corals and reef fishes. Curr. Biol. 24, 2946- 2951.

Ilham, L.M., Priosambodo, D., Moka, W., 2017. Penutupan Karang di Pulau Baranglompo dan Pulau Bone Batang Berdasarkan Metode Reef Check. SPERMONDE Vol. 3(1). Hal: 35-41. ISSN: 2460-0156.

Jupp, D.L.B., K.K. Mayo, D.A., Kuchler, D.R., Claasen, R.A.., Kenchington., P.R. Guerin., 1985. Remote sensing for planning and managing the Great Barrier Reef Australia. Photogrammetrica. 40: 21-42.

Kleypas, J.A.., Buddemeier, R.W., Archer, D., Gattuso, J-P., Langdon, C., Opdyke, B., 1999a. Geochemical consequences of increased atmospheric CO2 on coral reefs. Science 284:118120 .

Levine, A.S., Feinholz, C.L., 2015. Participatory GIS to inform coral reef ecosystem management: Mapping human coastal and ocean uses in Hawaii. Applied Geography. Volume 59, May 2015, Pages 60-69.

Lyzenga, D., 1981. Remote Sensing of Bottom Reflectance and Water Attenuation Parameters in Shallow Water Using Aircraft and Landsat Data. International Journal of Remote Sensing 2 (1): 71-82. doi: 10.1080/01431168108948342

Mark, S., Lauretta, B., Spencer, A.., Woodc, D., Joscelyne, A.., James, H., Philine, E., 2017. Mapping the global value and distribution of coral reef tourism. Marine Policy. 82: 104-113

Mumby, P.J., Green, E.P., Edwards, A.J., Clark, C.D., 1997. Coral reef substratemapping how much detail can remote sensing provide. Coral Reefs, 130, 193-202.

Nurdin, N., Grydehøj, A., 2014. Informal governance through patron-client relationships and destructive fishing in Spermonde Archipelago. Indonesia Journal of Marine and Island Cultures. Volume 3, Issue 2, December 2014, Pages 5459.

Nurdin, N., Komatsu, T., Rani, C., Supriadi., Fakhriyyah, S., Agus., 2016. Coral reef destruction of Small island in 44 years and destructive fishing in Spermonde Archipelago, Indonesia. $I O P$ Conference Series: Earth and Environmental Science Volume 47, Issue 1, Article number 012011.

Nurdin, N., Komatsu, T., Agus., Akbar, AS.M., Djalil, AR., Amri, K., 2015. Multisensor and Multitemporal Data from Landsat Images to detect Damage to Coral Reefs, Small Islands in the Spermonde Archipelago, Indonesia. Ocean Science Journal 50 (2) : 1-9.

Smith, SV., Buddemeier, R.W., 1992. Global change and coral reef ecosystems. Ann Rev Ecol Syst 23:89-118.

Turak, E., L. DeVantier., 2008. Biodiversity and Conservation Priorities of Reef-building Corals in North Halmahera-Morotai. Final Report. Conservation International. Indonesia. 68p.

Wahiddin, N., Siregar, V.P., Nababan, B., Jaya, I., Wouthuyzen, S., 2014. Deteksi Perubahan Habitat Terumbu Karang Menggunakan Citra Landsat Di Pulau Morotai Provinsi Maluku Utara. Jurnal Ilmu dan Teknologi Kelautan Tropis, Vol. 6, No. 2, Hlm. 507-524.

Wilkinson, C. (ed.)., 2000. Status of Coral Reefs of the World: 2000. Global Coral Reef Monitoring Network and Australian Institute of Marine Science, Townsville, Queensland, Australia, $363 \mathrm{pp}$.

Wouthuyzen, S., Abrar, M., Corvianawatie, C., Kusomo, S., Yanuar, Y., Darmawan., Yennafri., Salatalohi, A.., Hanif, A.., Permana, S., dan Arafat, M.Y., 2020. Kecenderungan Naiknya Suhu Permukaan Laut dan Resiliensi Karang Setelah Kejadian Pemutihan Karang 2010 dan 2016 di Taman Wisata Perairan (TWP) Pulau Pieh, Padang, Sumatra Barat. Oseanologi dan Limnologi di Indonesia 2020 5(1): 1-18. ISSN: 2477-328X. 